\title{
The empirical determination of key skills from an economic perspective
}

\author{
Citation for published version (APA):
}

van Loo, J. B., \& Toolsema, B. (2004). The empirical determination of key skills from an economic perspective. Researchcentrum voor Onderwijs en Arbeidsmarkt, Faculteit der Economische Wetenschappen. ROA Research Memoranda No. 3E https://doi.org/10.26481/umaror.200403E

\section{Document status and date:}

Published: 01/01/2004

DOI:

10.26481/umaror.200403E

Document Version:

Publisher's PDF, also known as Version of record

\section{Please check the document version of this publication:}

- A submitted manuscript is the version of the article upon submission and before peer-review. There can be important differences between the submitted version and the official published version of record.

People interested in the research are advised to contact the author for the final version of the publication, or visit the DOI to the publisher's website.

- The final author version and the galley proof are versions of the publication after peer review.

- The final published version features the final layout of the paper including the volume, issue and page numbers.

Link to publication

\footnotetext{
General rights rights.

- You may freely distribute the URL identifying the publication in the public portal. please follow below link for the End User Agreement:

www.umlib.nl/taverne-license

Take down policy

If you believe that this document breaches copyright please contact us at:

repository@maastrichtuniversity.nl

providing details and we will investigate your claim.
}

Copyright and moral rights for the publications made accessible in the public portal are retained by the authors and/or other copyright owners and it is a condition of accessing publications that users recognise and abide by the legal requirements associated with these

- Users may download and print one copy of any publication from the public portal for the purpose of private study or research.

- You may not further distribute the material or use it for any profit-making activity or commercial gain

If the publication is distributed under the terms of Article $25 \mathrm{fa}$ of the Dutch Copyright Act, indicated by the "Taverne" license above, 
The Empirical Determination of Key Skills from an Economic Perspective ROA-RM-2004/3E

Jasper B. van Loo, Bert Toolsema

Research Centre for Education and the Labour Market

Faculty of Economics and Business Administration Maastricht University

Maastricht, November 2004 
ISBN 90-5321-400-3

Sec04.109 


\section{Contents}

Page

Abstract

Acknowledgements

1 Introduction 1

2 Literature Review 1

3 Theoretical Framework 6

4 Method 9

5 Results 10

6 Conclusions and recommendations for future research 13

$\begin{array}{ll}\text { References } & 15\end{array}$ 



\begin{abstract}
Notwithstanding an impressive research tradition on key skills, no clear statistical criterion exists that is suitable to determine which skills may be considered key skills. This contribution proposes one possible methodology that can be used to identify key skills. Proposing an economic definition of the key skill concept and by disentangling the direct and indirect effects of skills on productivity, we develop an empirical criterion for the identification of key skills. We apply this methodology to a dataset of employed vocational education graduates. We find that problem-solving skills, independence, oral presentation/speaking skills, accuracy/carefulness and initiative/creativity may be considered key skills.
\end{abstract}

\title{
Acknowledgements
}

The authors thank the Netherlands Organization for Scientific Research (NWO) for financial support. This article aims to connect two tracks in the NWO-project The Production of Human Capital and the Position on the Labour Market. We also thank Lex Borghans, Hans Heijke, Christoph Meng, Tonette Rocco, two anonymous referees and the participants of the Human Capital Workshop held in Maastricht, December 15-16, 2003 for their constructive comments on earlier versions of this article. 



\section{Introduction}

Key skills are often regarded as skills that can be used productively in various work-related contexts, independent of specific tasks performed. While the scholarly debate on key skills has addressed definitional issues, the criteria for determining what skills may be considered key skills are rarely based on statistical arguments related to theory. Instead, both theorists and organizations tend to adopt criteria that depend on the importance of specific skills in organizational production processes. With the emergence of new ways of organizing work, for example, 'team working' skills have been stressed as key skills, while the diffusion of information technology in many workplaces has triggered an emphasis on Information and Communication Technology (ICT) skills.

The lack of a common understanding of key skills at the theoretical level prevents both the development of clear operationalisations of the concept and empirical testing. This hampers the useful application of key skills in policy and practice. While the ongoing discussions among scholars are valuable in terms of theory building, the lack of operationalisations and empirical application prevent the transfer of valuable insights on key skills from the academic community to the realms of meaningful practice and policy making.

In this contribution, we show that once a definition for key skills is chosen on the basis of suitable theoretical arguments, it is possible to develop a method that applies empirical criteria for determining which skills may be considered key skills. Two research questions are addressed:

1) Which skills may be considered 'key skills'?

2) How can these skills be identified empirically?

The remainder of this paper is organized as follows. By reviewing the literature in the next section, we focus on the two main reasons for the existing confusion in the debate on key skills: The approach of the concept from various theoretical backgrounds and international differences in key skill definitions. Next, we discuss our theoretical framework and the empirical criterion we apply to determine key skills. Using a dataset of employed intermediate vocational education graduates, the results of this exercise are presented in the next section. The final section summarizes and discusses possible avenues for future research.

\section{Literature Review}

The key skill concept originated in the 1970's with the German literature on key qualifications (Mertens, 1974) and the American literature on key skills (Pratzner, 1978). The development of the key skills concept can be seen as a reaction to the changes taking place in production processes which have demanded more flexibility in almost all types of work. Technological changes, organizational developments, competition and an increased attention for quality broaden the need for skills in the workplace and require employee development. To 
accommodate these changes and remain competitive, employing organizations increasingly require a flexible workforce with sufficient general qualifications (Watkins \& Marsick, 1993). From the 1970's onwards, a lively debate on key skills has emerged. This section summarizes two main elements that characterize this debate: different theoretical bases for discussions on skills and international differences in definitional issues. To expose some of the striking differences in this regard we summarize the main views on key skills in three countries: The USA, the UK and Germany.

\section{Different theoretical backgrounds in skill discussions}

Part of the confusion in the field of key skills has arisen due to the fact that the concept of skills has been studied from different theoretical backgrounds (Attewell, 1990; Vallas, 1990). Educational psychologists and human capital theorists use the skill concept to analyse properties of workers. They tend to treat skills as personal cognitive or physical fitness for task completion (Anderson, 1995; Gagné, Briggs, \& Wager, 1988). Human Capital theorists view skills as personal attributes that are required to add value to human resources (see e.g. Becker, 1962; Mincer, 1962). In sociology, on the other hand, skills are considered properties of jobs and perceived as means for workers to identify themselves with a specific vocational population (see e.g. Ellström, 1998). Sociological research on skills tends to be concerned with the consequences of change for the skill content of work. Two competing perspectives have traditionally dominated the sociological literature on skill change: upgrading theories, which assert that change increases the level of skill needed to perform effectively, and deskilling theories, in which change is seen as the cause of skill downgrading. Recently, however, research that integrates deskilling and upgrading by assuming that skill requirements are determined by several trends simultaneously (Zuboff, 1988) has attracted a lot of attention.

Since the skill concept has different meanings in various theoretical backgrounds, it is no surprise that key skill characteristics depend on the chosen research perspective. While human capital theory emphasizes the productivity effects of key skills, sociological research focuses on the essential skills that are needed in jobs. Accordingly, the meaning and interpretation of key skills varies substantially between scientific disciplines.

\section{Definition and international confusion}

Adding to the differences in research perspectives, there seems to be an international linguistic confusion about the key skill concept. In the United States key skills are usually called "basic skills" (e.g. Bynner, 1997) or "generic skills" (Stasz, 1998), whereas in continental Europe (e.g. Germany or the Netherlands) one speaks of "key qualifications" or "key competencies" (Bunk, 1994; Nijhof, 1998; Onstenk, 1997; Reetz, 1989a, 1989b). In the United Kingdom, key skills are often referred to as "core skills". Despite the fact that all these concepts are related, there are substantial international differences in the definition and interpretation of the key skill concept. 
Green (1998, p. 34-35), for example, describes how key (often referred to as 'core') skills emerged in the UK:

"Core skills have emerged out of an historical absence in the UK. Alone amongst the major European nations in the 19th century, England developed a technical and vocational education that had no inherent connection with general education and schooling. Whilst on the Continent, and particularly in France and the German speaking states, the typical form of vocational training was the state-sponsored trade school, which combined workshop training with systematic instruction in vocational theory and general education, in England, with its voluntarist traditions, there were few such schools and vocational as opposed to skills training had to evolve in an ad hoc and relatively unsupported fashion [...]"

In the UK, core skills sometimes refer to general, non-vocational skills that have been introduced in the vocational curricula in an attempt to capture the non-vocational skills acquired in vocational education and training systems (Tribe, 1996). This has resulted in the criticism that core skills only represent the low level minimal standards of the academic content in the UK's vocational education and training system: elements from general academic education are only transferred to the vocational curricula when they are directly related to performance in expected work tasks and when they can be reduced to core skills (Green, 1998, pp. 28).

Within the UK, some have regarded core skills as the way out of the over-specialized Alevels, or as a way to bridge academic and vocational tracks. In the context of the UK's vocational education and training system, however, others have argued that core skills are means through which skills or qualifications can be transferred to multiple (vocational) contexts (Green, 1998). Therefore, core skills particularly refer to the core of functioning at work and reside in the training and vocational branch of education (Tribe, 1996). The basic ideas of the UK core skills tradition can be linked to a list set up by the Further Education Unit in 1979. According to this document, core skills were supposed to:

- bring about an informed perspective as to the role and status of a young person in an adult society and the world of work;

- provide a basis from which the person can make an informed and realistic decision with respect to his or her immediate future;

- bring about continuing development of physical and manipulative skills;

- bring about an ability to develop satisfactory personal relationships with others;

- provide a basis on which the young person acquires a set of moral values applicable to issues in contemporary society;

- bring about a level of achievement in literacy, numeracy and graphicity appropriate to ability and adequate to meet the basic demands of contemporary society;

- bring about competence in variety of study skills;

- encourage the capacity to approach various kinds of problems methodically and effectively, and to plan and evaluate courses of action;

- bring about political and economic literacy; 
- encourage an appreciation of the physical and technological environments and the relationship between these and the needs of man in general, and working life in particular;

- bring about a development of the coping skills necessary to promote self sufficiency in young people;

- bring about a flexibility of attitude and a willingness to learn, sufficient to manage future changes in technology and career.

(Tribe, 1996, p. 13-14)

The elements in this list all refer to skills that are generic and transferable, which means that they are applicable to a wide variety of occupations and transferable to many contexts. Since it features some elements that are clearly overlapping, a number of core skill lists have followed. A number of aspects, however, feature prominently in most lists. According to Tribe (1996), most of the lists include: communications, numeracy, problem solving, teamwork, and technology skills. However, the question of which skills should be on the lists of key skills has not been approached using theoretical criteria. In practice, core skills tend to be those skills that are subjectively needed for education, everyday life and work (QCA, 2000).

\section{The US perspective}

One of the early American examples of the use of key skills in practice can be found in 1983 in the district of Lewisville, Texas. A Superintendent's Advisory Committee conducted a study in order to determine the desired key skills of students graduating from High School. They developed a questionnaire, which was sent to community members and officials from the business and professional community. Respondents were asked to rate the skills they found important. The 62 surveyed skills fell into nine categories. The skill categories rated "important" or "extremely important" by $80 \%$ or more of the members of the business and professional community were:

- Decision-making Skills;

- Future Plans;

- Life Coping Skills;

- Physical, Social, and Personal Health;

- Computational Skills.

(Killian, 1983)

In the late 1980's two major studies were undertaken by the Hudson Institute and the American Society for Training and Development (ASTD) to track the changes taking place in the workplace and to identify the implications in terms of key skills (Van Zolingen, 2002). Carnevale (1991) lists seven skill dimensions that are required for effective workplace performance:

- Learning to learn;

- Academic basics;

- Communication;

- Adaptability;

- Personal development;

4 
- Group effectiveness;

- Influencing skills.

The SCANS commission that was set up in 1991 further developed a framework of key skills. This framework is composed of five workplace competencies and three personal skills and qualities that are needed for job performance. In the US setting, key skills have also been analysed using the Dictionary of Occupational Titles (DOT or O NET) framework. This is a large-scale job analysis which relies on information on thousands of jobs in the US, with the obvious disadvantage that the information in the database is concentrated on jobs rather than on individuals.

It is important to note that in the US context, key skills refer to the most important or desired skills. These key skills are quite different from the core skills found in the UK, which are of a generic and transferable nature.

\section{The German perspective}

A more systematic and theory-based approach to key skills is applied in the German context. Mertens (1974), for instance introduced the concept of key qualifications as a reaction to the need to transfer skills to multiple situations and context. Mertens distinguishes between four types of key qualifications:

- Basic qualifications: referring to basic skills which facilitate the transfer of knowledge;

- Horizontal qualifications: referring to skills for processing information;

- Broad elements: referring to skills which can be used in several places;

- Vintage factors: which should absorb the alternation of generations.

Inspired by the concept of key qualification, Bunk (1994) has developed a theory of vocational competence. Taking the history of vocational education into account, Bunk introduces the concept of "participatory competence", which refers to taking responsibility in and for the organisation one works for. According to Bunk, from the sixties onwards, work has required more than just specialised working skills. Throughout the years more types of skills are added to those specific skills. Subsequently the following types of skills are needed:

- Specialised competence: are skills (and knowledge) for carrying out activities and tasks in specific fields of work.

- Methodological competence: are skills needed to react to problems and to procedural activities in unusual situations.

- Social competence: are skills for communication and cooperation, as in teamwork and interpersonal understanding.

- Participatory competence: are skills to shape the working environment at their own workplace and beyond, as in planning ahead, assuming organizational tasks, decision making and taking responsibility.

The scope of skills widened in three aspects. Firstly, individuals should be able to work in different situations and context. Secondly, individuals should not only be responsible for their 
own work, but must include the social environment in their work as well. Thirdly, individuals must widen their scope from their own working situation to the organisation as a whole.

Unlike the Anglo-Saxon approach the German approach is more clearly based on theoretical assumptions rather than on pragmatic reasons. The latest theoretical discussions in Germany focus on the ways the necessary skills should be acquired. The overall opinion is that these skills should be learned as close to the work context as possible. Key skills, which are applicable in different contexts, should be acquired in a context-bound setting in which both schools and companies can fulfil different roles (DIHT, 1999). They are context-bound in the sense that they obtain their true meaning in the specific context they are used. But they can be adopted in multiple contexts.

\section{Theoretical Framework}

To analyse the key skill concept in a meaningful way, we need to select a theoretical starting point. In this contribution, we adopt an economically-inspired human capital approach of the key skills concept. Therefore, within the scope of this paper, we opt for economically inspired definitions of skills and key skills. Three assumptions guide our definition of skills. First, we consider skills to be individual and related to productivity, restricting the scope to work. Second, skills may originate from different sources. They may have been developed or shaped by means of education and training or experience, or innate: not developed but related to attitudes or personality. It is important to recognize that physical attributes, such as gender and height cannot be considered skills. For example: Tall men may be better basketball players than short men, but the associated difference in skills cannot be expressed by height. Rather, characteristics such as the ability to score, to jump or to catch the ball, which may be related to height, are the relevant skills. And finally, we consider skills to be context-bound, since they are developed and applied in specific contexts of human activity (e.g. in a specific job, with specific restrictions, or in a specific organization) (Chi, Glaser, \& Farr, 1988). Recently Toolsema (2003) reconfirmed the importance of a contextbound approach in his study on work-related competencies. He found that competencies are context-bound personal assets. Some competencies however, like information processing, career development and learning are less context-dependent. In a similar manner, key skills must be context-bound but less context-dependent than other skills.

Among others, Stasz (1998) has argued that the modern workplace is changing because of technological innovations, flatter organizational hierarchies, and increasing globalization of markets. These changes have caused a higher demand on the flexibility of the workforce, which is reflected in hiring decisions of employers. Employers increasingly demand "generic skills" next to job-specific skills. Although research by Bishop, (1997) showed that jobspecific skills are still among the most wanted productivity-related skills, he admits that the more general and context-independent skills are important as well. Bishop, focusing at the productivity effects of skills, reflected in the wage and employer satisfaction, argues that skills like reading and mathematical skills "contribute to productivity by helping the individual learn the occupational and job specific skills that are directly productive". In other words there is a distinction between direct and indirect productivity. And because key skills should 
provide the flexibility to work in different contexts and situations, these are the skills which are likely to have indirect effects on worker productivity.

When skills have both a direct and an indirect effect on productivity, key skills can be determined using the magnitude of the different effects as a criterion. When key skills mainly impact productivity indirectly, by increasing the levels of other skills and the magnitude of the indirect effect is the essential characteristic of key skills, they may be defined as:

\section{Individual (developed or innate) characteristics representing context-bound productivity that mainly impact productivity in an indirect manner}

The contribution of skills to economic success, and in particular to productivity, can be measured in several ways (Levy \& Murnane, 1999). For example, one could determine the relative importance of skills to employers by studying selection criteria. One could also relate wage inequality of groups within a population to skills profiles, similar to existing comparisons of educational qualifications of groups earning higher wages to those earning less. A third option might be an ethnographic approach, in which one studies in detail which changes took place within production, service industry and public sector work and their consequences for skill requirements. A final option would be to determine skills effects in a mathematical way by relating skills to wages.

In economics the determination of skills that matter for wages has a rich history in the literature. In the well-known human capital literature (Becker, 1962; Mincer, 1974), skills are essentially divided into being either general or specific. Later, attention has been paid to skills that fall in between, so-called 'transferable skills' (Stevens, 1994). The attention for skills as such, opposite to composites of human capital, has led to the development of research that addresses the contribution of different types of skills to productivity or wages (Levy and Murnane, 2001). The empirical relation between skills and wages can be expressed as follows:

$$
\ln W_{i}=\beta_{0}+\beta_{1} S_{1 i}+\ldots \beta_{N} S_{N i}+\varepsilon_{i}
$$

Equation (1) is a hedonic wage equation that relates $N$ different skills to individual (i) log wages (Dickerson and Green, 2004). Using this approach to determine the contribution of skills to productivity has one major drawback. It focuses on the relations between skills and wages only, while ignoring the relation between different skills. The relation among skills is essential when one tries to determine what skills are key skills. In addition, including all relevant skills into a single wage equation potentially leads to estimation problems, as typically, a number of skills tend to be highly correlated. Using principal components analysis or similar data reduction algorithms would be an option to deal with this multicollinearity, but can not be used to determine the value of individual skills.

In order to address these issues, we present a different empirical approach for determining key skills that is consistent with the definition discussed earlier. In order to focus on the 'key' 
nature of some skills, we explicitly take into account the relations that exist between the different skills distinguished. We do this by combining the relationships between the different skills with the wage regression. When key skills are considered to be those skills that make other skills more productive, we may set up the following empirical model:

$$
S_{i n}=c_{n}+\sum_{j=1}^{N, j \neq n} \beta_{j n} S_{i j}+\varepsilon_{i n}
$$

For all skills $\left(S_{n}, n=1 \ldots N\right)$ equation $(2)$ relates $S_{n}$ to a constant and all other skills $\left(S_{j}, j=1 \ldots N\right.$ and $j \neq n$ ). The $\beta$ 's in this equation constitute the contribution of a skill to another skill. Generally, we would expect these contributions to be positive. A negative $\beta$ would imply that a skill would have a negative impact on another skill. It is possible for skills to be unrelated to other skills, but in that case $\beta$ would be close to zero. In order to find the indirect effect of a skill j, we add up all the contributions of this skill to other skills, or in formal terms:

$$
\gamma_{j}=\sum_{n=1}^{N, j \neq n} \beta_{j n}
$$

Equation (3) represents the criterion we apply in this contribution to determine which skills may be considered key skills. This criterion is expressed in terms of skill levels. A skill is a key skill when a unit increase in that skill leads to a larger cumulative increase in all other skills. In terms of equation (3) a skill is a key skill when $\gamma_{j}>1$.

Since we are also interested in the magnitude of the effects of key skills on productivity (log wages) we calculate both direct and indirect wage effect of all skills as follows:

$$
\ln w_{i}=\alpha+\beta_{n} S_{i n}+\varphi_{j} \sum_{j=1}^{N, j \neq n} S_{i j}+\lambda X_{i}+\varepsilon_{i}
$$

This equation relates a skill $n$, the summation of all other skills and control variables $\left(X_{i}\right)$ to wages. We use (3) and (4) to determine the marginal wage effect of a change in the skills. The direct wage effect of a marginal change in $S_{i n}$ is $\beta_{n}$. A change in $S_{i n}$, however, also has an indirect effect on all other skills, namely $\gamma_{j}$ (equation 3). Since we are dealing with marginal changes, $\gamma_{j}$ can also be considered as the total change in $\sum_{j=1}^{N, j \neq n} S_{i j}$, implying that the total indirect wage effect is $\gamma_{j} \cdot \varphi_{j}$. Put differently: each skill-wage equation is composed of two effects of skills on wages: a direct and an indirect effect.

\section{Limitations}

The theoretical framework we use to determine which skills may be considered key skills has three main limitations. The first limitation concerns causality. Since we use ordinary least 8 
squares to estimate equation (2), it is difficult to establish the direction of causality. Since we have no prior assumptions on the direction of causality or a time series dataset that enables us to establish causality by relating events taking place at different points in time, the proposed framework only informs us on the association between different skills. In the absence of information on the direction of the causality, we will most likely find more skills that are designated key skills: If two skills (S1, S2) impact each other (S1 causing $\mathrm{S} 2$ and S2 causing S1) they will have strong effects in the skill-equations which have S1 and S2 as the dependent variable. This makes it more likely that they both become key skills.

The second limitation concerns the effects of multicollinearity between skills. Strong multicollinearity might make it less likely that some skills will become key skills. If two skills $(\mathrm{S} 1, \mathrm{~S} 2)$ are highly correlated, they might not yield significant coefficients in the skill equation that has, for instance, S3 as the dependent variable. Dealing with the effects of causality and multicollinearity effects simultaneously would require the development of a more advanced statistical method, which is beyond the scope of this article.

Another limitation of the framework is that the statistical approach only looks at first-order effects in the determination of key skills. It uses the estimated parameters to calculate the effects of a change in one skill on all other skills without taking account of the subsequent higher order effects. When a skill S1 has an impact on both S2 and S3, the total indirect effect of S1 is calculated as the summation of the effects on S2 and S3. The framework does not take into account that as a result of a change in $\mathrm{S} 1, \mathrm{~S} 2$ changes, which again impacts the level of S3.

\section{Method}

We apply the model for determining key skills to data from a graduate survey of Dutch intermediate vocational education graduates. Using graduate data has the obvious advantage that the obsolescence of skills, that typically takes place later in careers, has not yet occurred. The respondents where approached approximately one year after they graduated. During October-December 1999, 18,513 questionnaires were sent out, of which 9,068 were returned. A little over 1,000 questionnaires were not suitable for data-entry, so that 7,889 cases remained. In order to focus on a group that is relatively similar in terms of activities, we selected those respondents who were working full-time (at least 35 hours) in an organization (we excluded self-employed graduates). This left us with 1,702 cases for analysis.

The part of the questionnaire that is of particular interest for this paper is the list of skills. For fifteen different skills, respondents where asked to indicate on a 5 point Likert scale to what extent the listed aspects are required in their work. Using the data from these fifteen skill measures we approached skill by the so-called 'competence-in-use' concept (see Ellström, 1998), implying that skills are measured by the interaction between individual capacities and job requirements. Table 1 gives an overview of the skills investigated together with their average scores and standard deviations. 
S1. Professional theoretical knowledge

$\begin{array}{ll}4.21 & 0.99 \\ 3.84 & 1.08 \\ 3.60 & 1.09 \\ 4.07 & 1.04 \\ 3.48 & 1.12 \\ 3.95 & 1.06 \\ 4.00 & 0.96 \\ 3.85 & 1.10 \\ 4.36 & 0.84 \\ 4.31 & 0.85 \\ 4.47 & 0.84 \\ 4.60 & 0.69 \\ 4.47 & 0.77 \\ 4.37 & 0.80 \\ 4.67 & 0.71\end{array}$

\section{Results}

In this section, we apply the empirical model to the data. In order to find the indirect skill effects, we performed for each skill a separate regression on all the other skills. In table 2, we provide the regression estimates of the parameters of the explanatory skills in the 15 skill regressions. The standard errors appear in parentheses. For convenience, the nonsignificant coefficients are shaded.

Table 2 summarizes the estimation results for 15 regression analyses in which each skill is related to all other skills. The table reveals that of the 210 coefficients estimated, 78 are not significant and therefore shaded. Of these 78 non-significant coefficients, 32 have a negative sign. Within the group of significant coefficients, twenty coefficients have a negative effect, while 112 coefficients have the expected positive effect.

In the second part of the analysis, we estimate for each skill the wage equation (4) that relates the level of a skill $S$ and the summation of all other skill levels to log wages. In order to take account of wage differences caused by gender or experience, we included three control variables: gender, age and age-squared. Since we use a dataset on graduates, jobtenure is difficult to operationalize due to high mobility of graduates in the first stage of their career. Therefore, age and age-squared were included to reflect the acquisition of experience. Age, age-squared and gender have consistent effects in all 15 skill-wage equations: Females earn approximately $10 \%$ less than males, the marginal effect of age is around $4.5 \%$ and the effect of age-squared is negligible. 


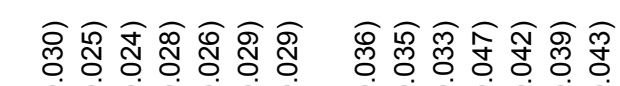
宅宅宅宅宅

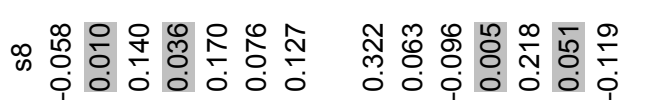

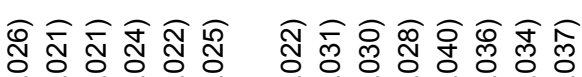
过宅宅 $\dot{\theta} \dot{\theta} \dot{\theta} \dot{\theta} \dot{\theta}$

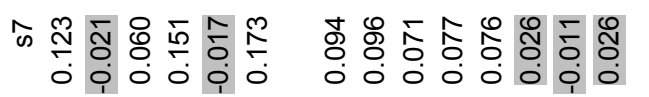

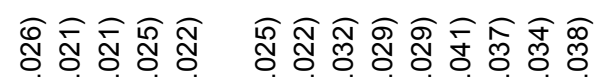
过宅运

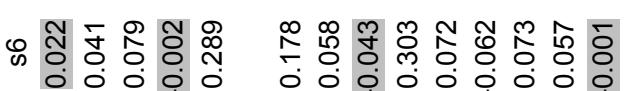

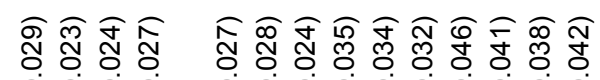

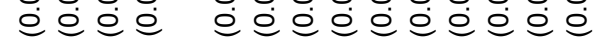

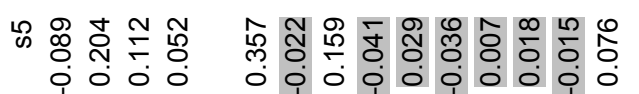

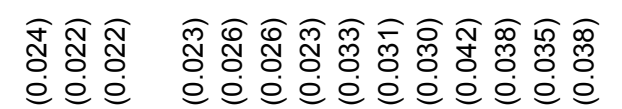

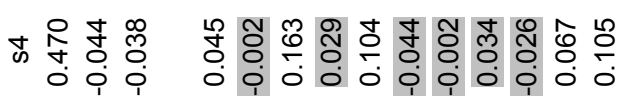

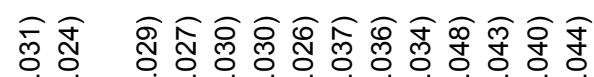

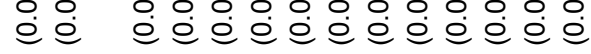

m

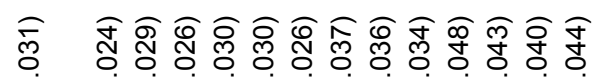

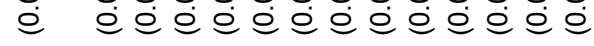

๙

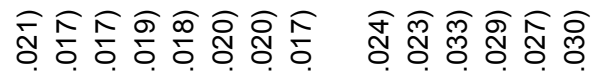

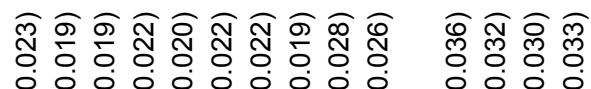

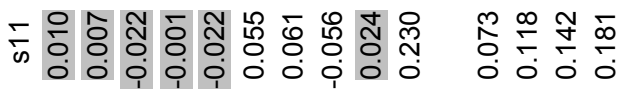

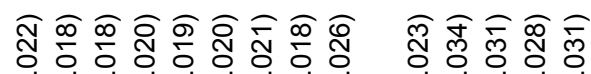

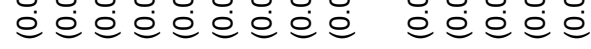

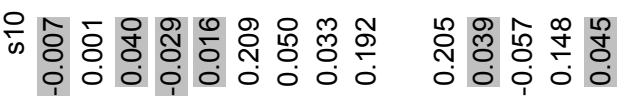

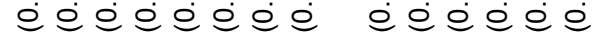

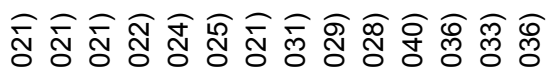
$\dot{\theta} \dot{\theta} \dot{\theta} \dot{=} \dot{\theta} \dot{\theta} \dot{\theta} \dot{\theta} \dot{\theta} \dot{\theta} \dot{\theta}$

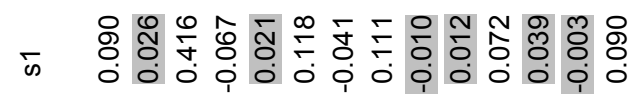

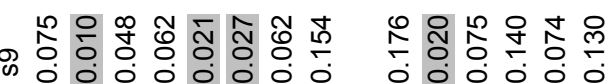

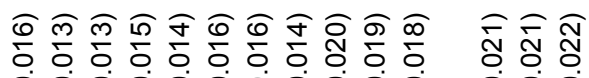

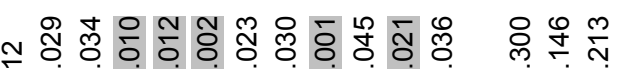

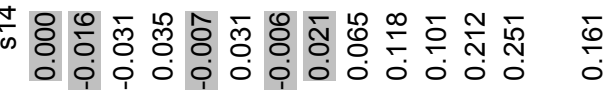

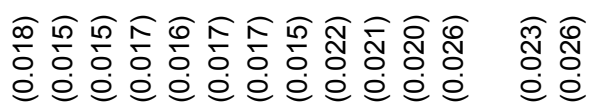

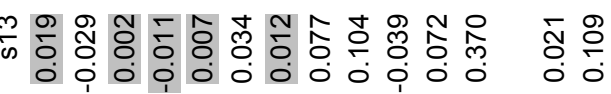

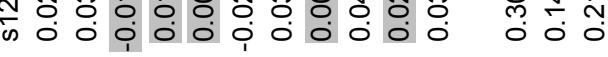

O000000

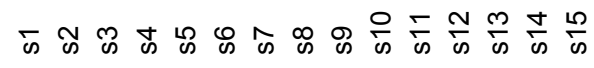




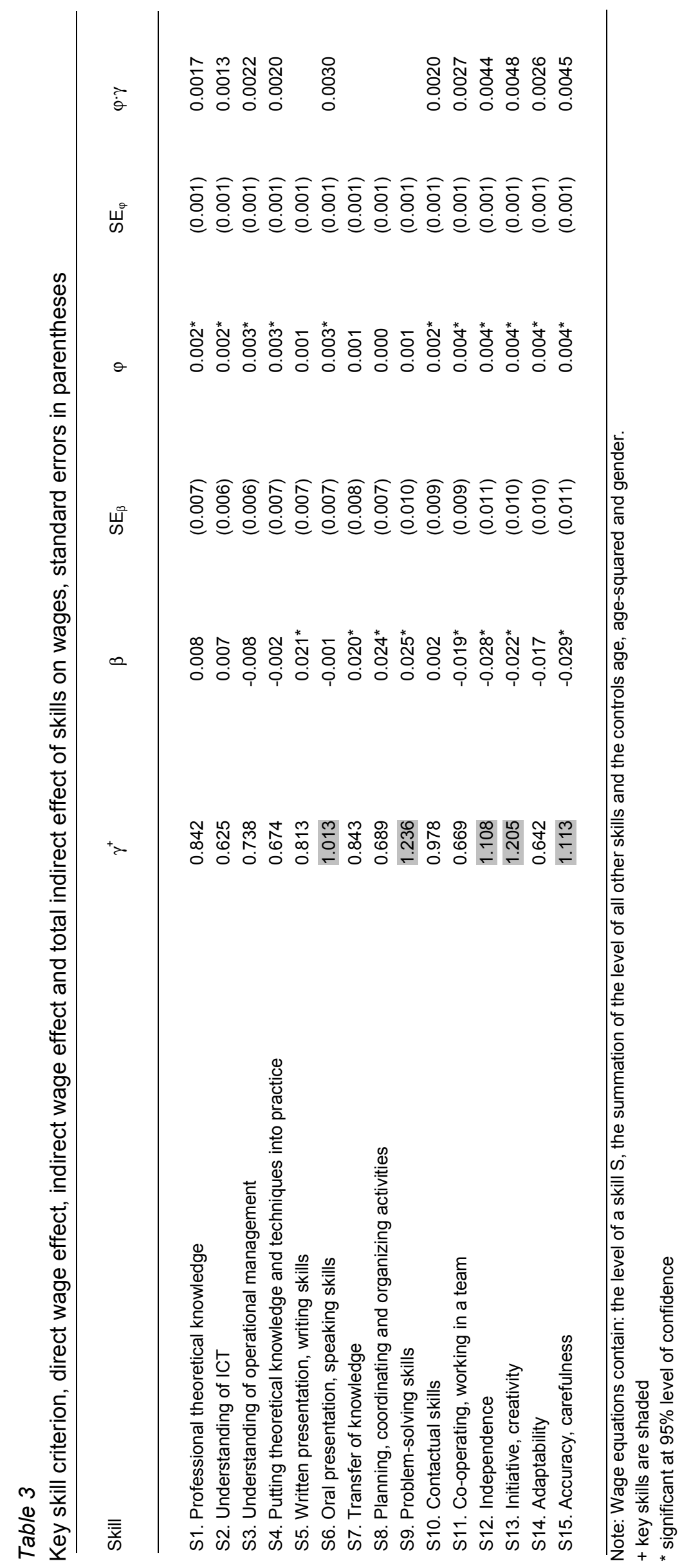


In table 3 we provide for each skill the value of the key skill criterion $\gamma_{\mathrm{j}}$, the direct and indirect wage effects from the wage regressions we performed, and the total indirect wage effect $\gamma_{\mathrm{j}} \cdot \varphi_{\mathrm{j}}$. The first column specifies the value of the key skill criterion. For each skill, it is calculated by taking the summation of all positive and significant effects of that skill on all other skills. The skills that have a cumulative effect on all other skills that is larger than one are shaded. According to the criterion defined earlier, these five skills may be considered key skills:

- Problem-solving skills;

- Independence;

- Oral presentation/speaking skills;

- Accuracy/carefulness;

- Initiative/creativity.

When these outcomes are compared to several lists of key skills published in the literature, we find a number of skills that are comparable. A notable exception to this are ICT-skills. Toolsema (2003) also found that ICT-competencies are context specific rather than context independent, which implies that the key nature of these skills is possibly less important than often suggested.

The table shows that writing skills, transfer of knowledge, planning/coordinating/organizing activities and problem solving skills all have significant positive direct wage effects of around $2 \%$. In contrast, co-operating/working in a team, independence, initiative/creativity, adaptability, and accuracy/carefulness all have significant negative direct effects on wages.

Column 4 shows that for the 15 skills distinguished, there are significant and positive effects from all other skills on wages in the range of $0.2-0.4 \%$. The final column displays the total indirect wage effect from key skills. It reveals that these effects are largest for independence, accuracy/carefulness and initiative/creativity. For the skills that have no significant indirect effect on wages, the total indirect wage effect $(\varphi \cdot \gamma)$ has no meaningful interpretation and is therefore not shown.

\section{Conclusions and recommendations for future research}

Despite a large body of literature a generally accepted theory on key skills has not yet been established. Instead, key skills play an eminent role in the current debates on the importance of skills and lifelong learning. Elements of this debate are different definitions for key skills, different criteria for key skills, and different theoretical bases for key skills discussions.

Our goal in this contribution has been to develop one possible empirical methodology that is based on an economic perspective of key skills. In order to develop such a methodology, it is essential that single definitions for skills and key skills are chosen. When skills are individual and related to productivity, originate from various sources (education, training, experience, personality) and context-bound, they may be defined as: Individual (developed or innate) 
characteristics representing context-bound productivity. The criterion of context-bound might seem competing to that of flexibility. In our approach key skills are context-bound but less context-dependent than other (non-key) skills. The difference is to be found in "more" or "less" not "either" and "or" (Toolsema, 2003). The selected economic perspective on key allows the introduction of a quantitative criterion for key skills. Our definition of key skills is related to the distinction between direct and indirect effects on productivity. Key skills impact productivity indirectly, by increasing the level of other skills. When the summation of the increases in all other skills outweighs a unit increase in one particular skill, that skill is considered to be a key skill.

We present an empirical framework that can be used for the determination of key skills that is based on our key skill definition. When we apply this framework to a sample of graduates, five skills that may be considered key skills emerge: problem-solving skills, independence, oral presentation/speaking skills, accuracy/carefulness, and initiative/ creativity. It is comforting that in many lists of key skills, similar aspects are included as being key skills. A striking difference with a number of recent lists of key skills is that ICT skills, which are often considered essential in the modern workplace cannot be identified as a key skill. A possible explanation for this finding is that we are analyzing intermediate vocational education graduates, which typically use ICT skills connected to a specific task. In addition, recent work on competences shows that the key nature of these skills is possibly less important than often suggested.

A shortcoming of our analysis is that we cannot justify the choice of the fifteen skills we used in the empirical part of this contribution. In addition, the focus on graduates of a national vocational education system clearly compromises on the generalizability of the findings. Another issue that needs attention is the dependence of the reported outcomes on the applied definition of key skills. Finally, the issue of causality needs additional attention in future research.

The main contribution of this paper to the debate on key skills is that it was shown that a empirical approach can be used to determine which skills are key skills and which are not. Future research should focus on generalizing the findings by looking at different groups of workers, expanding the set of skills used in the analyses, using different definitions of key skills and developing alternative models to the one we have proposed in this paper. If a number of these models point into the direction of the same set of key skills, this would imply a significant advance in the relevance of the key skill concept and its application in educational curricula, continuing education, government policies and career management practices. 


\section{References}

Anderson, J. (1995), Development of Expertise: Cognitive Psychology and its Implications, New York, W.H. Freeman and Company.

Attewell, P. (1990), What is Skill, Work and Occupations, 17(4), pp. 422-448.

Becker, G.S. (1962), Investment in Human Capital: A Theoretical Analysis, Journal of Political Economy, 70(5), pp. 9-49.

Bishop, J. (1997), Expertise and Excellence: Skill Development in the United States, in: B.W.M. Hövels, W.J. Nijhof, A.M.L. van Wieringen and M. van Dyck (eds.), Beroepsonderwijs en Volwasseneneducatie Nader Bekeken, Den Haag, VUGA Uitgeverij.

Bunk, P. (1994), Teaching Competence in Initial and Continuing Vocational Training in the Federal Republic of Germany, European Journal of Vocational Training, 1(1), pp. 8-14.

Bynner, J.M. (1997), Basic Skills in Adolescents' Occupational Preparation, Career Development Quarterly, 45(4), pp. 305-321.

Carnevale, A.P. (1991), America and the New Economy, (San Francisco, Jossey-Bass).

Chi, M.T.H., Glaser, R., \& Farr, M.J. (eds.) (1988), The Nature of Expertise, Hilsdale, Lawrence Erlbaum Associates.

DIHT (1999), Leitlinen Ausbildungsreform, Wege zu einer modernen Beruflichkeit, Bonn, Deutsche Industrie und Handelstag.

Ellström, P. (1998), The Many Meanings of Occupational Competence and Qualification, in: W.J. Nijhof \& J.N. Streumer (eds.), Key Qualifications in Work and Education (Dordrecht, Kluwer Academic Publishers).

Gagné, R.M., Briggs, L.J., \& Wager, W.W. (1988), Principles of Instructional Design (New York, Holt, Rinehart and Winston).

Green, A. (1998) Core Skills, Key Skills and General Culture: in Search of the Common Foundation in Vocational Education, Evaluation and Research in Education, 12(1), pp. 23-43.

Green, F. (2004), The Growth and Valuation of Computing and Other Skills, Oxford Economic Papers, 56, pp. 371-406.

Levy, F. \& R.J. Murnane (1999), Are there Key Competencies Critical to Economic Success?: an Economics Perspective, Deseco Expert Report, Neuchâtel, Swiss Federal Statistical Office.

Levy, F., \& Murnane, R.K. (2001), Key Competencies Critical to Economic Success, in D. S. Rychen \& L. H. Salganik (eds), Defining and Selecting Key Competencies, Göttingen, Hogrefe \& Huber Publishers.

Merrifield, J. (2000), Equipped for the Future Research Report, Building the Framework, 1993-1997, EFF Technical report EX 106 P, Washington, DC, National Institute for Literacy.

Mertens, D. (1974), Schlüsselqualifikationen, Thesen zur Schulung für eine moderne Gesellschaft, MittAB, 1, pp. 24-25.

Mincer, J. (1974), Schooling, Experience and Earnings, New York, Columbia University Press.

Nijhof, W. J. (1998), Qualifying for the future, in: W.J. Nijhof \& J.N. Streumer (eds), Key qualifications in work and education, Dordrecht, Kluwer academic publishers.

Onstenk, J.H.A.M. (1997), Lerend Leren Werken, Brede Vakbekwaamheid en de Integratie van Leren, Werken en Innoveren, Unpublished Theoretical and case studies, Amsterdam, UVA.

Palomar College (1999), District Priorities for Institutionalization Project; Narrative [Web: http://www.palomar.edu/alp/GrantNarr.html], ALP (Assessment of Learning Project)-Team [retrieved 2001, October 4]. 
Pratzner, F.C. (1978), Occupational Adaptability and Transferable Skills: Project Final Report, Information Series 129, National Center for Research in Vocational Education, The Ohio State University.

QCA. (2000), Key Skills, Web: http://www.qca.org.uk/keyskills/what_are_ks.htm, retrieved December 1, 2000.

Reetz, L. (1989a), Zum Konzept der Schlüsselqualifikationen in den Berufsbildung (Teil I), BWP, 5, pp. 3-10.

Reetz, L. (1989b), Zum Konzept der Schlüsselqualifikationen in den Berusfsbildung (Teil II), BWP, 6, pp. 24-30.

Shaw, S. (1998), Development of Core Skills Training in the Partner Countries, Torino, Italy, European Training Foundation.

Stasz, C. (1998), Generic Skills at Work: Implications for Occupationally-oriented Education, in: W.J. Nijhof \& J.N. Streumer (eds.), Key qualifications in work and education, Dordrecht, Kluwer academic publishers.

Stevens, M. (1994), A Theoretical Model of On-the-Job Training with Imperfect Competition, Oxford Economic Papers, 46, pp. 537-562.

Toolsema, B. (2003), Werken met Competenties: naar een Instrument voor de Identificatie van Competenties (Ph D. Thesis), Enschede, University of Twente.

Tribe, J. (1996), Core Skills: a Critical Examination, Educational Review, 48(1), pp. 13-27.

Vallas, S.P. (1990), The Concept of Skill, a Critical Review, Work and Occupations, 17(4), pp. 379398.

Watkins, K.E., \& Marsick, V.J. (1993), Sculpting the Learning Organization, Lessons in the Art and Science of Systemic Change (First ed.), San Francisco, Jossey-Bass Publishers.

Zolingen, S.J van (1995), Gevraagd: Sleutelkwalificaties, Een Studie naar Sleutelkwalificaties voor het Middelbaar Beroepsonderwijs (Ph. D. Thesis), University of Nijmegen.

Zolingen, S.J. van (2002), The Role of Key Qualifications in the Transition from Vocational Education to Work, Journal of Vocational Education Research, 27(2), pp. 217-242.

Zuboff, S. (1988), In the Age of the Smart Machine: The Future of Work and Power, New York, Basic Books. 